\title{
INSPIREE:
}

\section{Seberapa Besar Pengaruh Panjang Tungkai terhadap Hasil Atletik Triple Jump?}

https://doi.org/10.53905/inspiree.v1i3.24

\author{
*Herli Pardilla abcde(C), Iqbal Husnayadi
}

'Program Studi Pendidikan Jasmani, Kesehatan dan Rekreasi, Universitas Pahlawan Tuanku Tambusai, Riau, Indonesia. ${ }^{2}$ Department of Shariah and Law, International University of Africa, Sudan.

\begin{abstract}
Tujuan Penelitian. Secara umum tujuan penelitian untuk mengetahui seberapa besar pengaruh panjang tungkai kaki Terhadap Hasil Atletik Triple Jump pada Unit Kegiatan Mahasiswa (UKM) Penjas Universitas Pahlawan Tuanku Tambusai.

Metode Penelitian. Pendekatan kuantitatif, metode survei dengan teknik pengukuran dan tes merupakan pendekatan metodologi dalam penelitian ini. Jadi, model path analysis digunakan untuk menganalisis pola hubungan antar variabel dengan tujuan untuk mengetahui pengaruh langsung seperangkat variabel bebas (eksogen) terhadap variabel terikat (endogen). Metode ini dilakukan pada populasi sasaran (target population) penelitian adalah seluruh atlet Triple Jump yang berjumlah 33 atlet.

Hasil. Setelah melakukan penelitian, maka hasil penelitian yang diperoleh adalah terdapat pengaruh yang positif dan signifikan panjang tungkai dengan pukulan smash sebesar $(r=0.472)$ dan $\left(r^{2}=0.472=0.472^{2}=0.2228\right)$ dengan kontribusi panjang tungkai memberikan kontribusi sebesar $22.28 \%$ terhadap hasil Atletik Triple Jump

Kesimpulan. Dalam olahraga atletik triple jump sangat dipengaruhi oleh variabel panjang tungkai dan singkatnya dengan panjang yang maksimal seorang atlet akan bisa meraih lompatan terjauh.
\end{abstract}

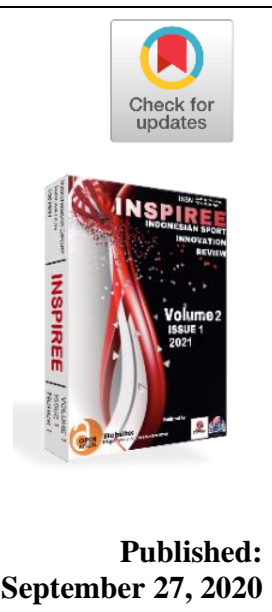

Keywords: panjang tungkai; atletik triple jump.

PENDAHULUAN

Olahraga Prestasi disamping memiliki pengembangan peningkatan pengetahuan dan keterampilan tekhnis di bidang cabang olahraga, atlet juga mendapatkan pembelajaran tentang nilai-nilai sosial yang positif serta dapat menanamkan sifat-sifat sportifitas yang tinggi sesuai dengan tujuan pendidikan olahraga tersebut. Salah satu olahraga yang dipertandingkan untuk mencapai tujuan tersebut adalah olahraga atletik.

Atletik merupakan salah satu cabang yang dipertandingkan atau diperlombakan yang terdiri atas nomor-nomor yaitu: jalan, lari, lompat dan lempar. Dalam nomor lompat salah satunya yang diperlombakan adalah nomor 
lompat jangkit. Lompat jangkit juga merupakan nomor atletik yang diajarkan di tingkat perguruan tinggi dengan unsur-unsur teknik dasar terdiri dari awalan, tumpuan, melayang di udara dan mendarat. Lompat jangkit adalah rangkaian suatu gerak lari, lompat dengan suatu gerakan yang cepat dari lompatan-lompatan atau tumpuan yang telah ditentukan yaitu dua kali jingkat kaki yang sama dan satu kaki yang lain dengan gerakan yang tidak terputus dan Lompat jangkit sering disebut lompat tiga, dalam bahasa inggris disebut juga Triple jump (Djumidar, 2004). Lompat jangkit sering disebut lompat tiga, dalam bahasa inggris disebut juga Triple jump, dikatakan lompat tiga, karena lompat jangkit ini terdiri dari tiga lompatan yaitu jingkat, langkah, dan lompat, atau dalam bahasa inggris nya hop, step, dan jump (Adang Suherman, 2001)

Kemudian dalam pelaksanaan lompatjangkit ada urutan teknik yang harus dilakukan yaitu jingkat (hop), melangkah (step), dan melompat (jump). Untuk dapat berprestasi dengan baik dalam lompat jangkit, ada beberapa aspek faktor yaitu kondisi fisik, anatomi dan fisiologis diantaranya yang mempengaruhinya adalah kekuatan, panjang tungkai, kelenturan, koordinasi, kecepatan, keseimbangan, kelincahan, kelenturan, indek masa tubuh atau ketebalan lemak dan faktor psikologis atlet. Di samping itu cabang olahraga atletik terutama nomor lompat jangkit juga memerlukan teknik-teknik gerakan yang tepat dalam gerakan lompatan. Menurut Fred Mc Mane (2008) pada bagian lompat yang harus di capai adalah ketinggian. Saat melayang serta pendaratan sama seperti lompat jauh, serta berusaha menjaga dengan baik keseimbangan serta mengangkat kaki ke atas sampai detik terakhir

Dan pada pola melayang bergerak dari rendah dan panjang saat melakukan jingkat, pola lebih tinggi pada tahap langkah. Proses yang sama ini berlanjut pada tahap lompatan. Saat kaki atlet melakukan pendaratan pada tahap langkah, kaki itu kehilangan lebih banyak kecepatan harizontal. Dan saat atlet kehilangan kekuatan sewaktu bertolak, sudut tolakan harus ditingkatkan untuk mengimbanginya (Mark Guthrie, 2003). Untuk mencapai jarak terjauh, atlet harus mengimbangi usaha pada ketiga lompatan yaitu pada jingkat (hop), langkah (step) dan jump, ini berarti atlet lompat jangkit tidak hanya seorang sprinter yang baik, tapi juga mempunyai kekuatan 
panjang tungkai otot dan kelenturan untuk memantul pada tiga kali lompatan yang berurutan (Gerry A. Carr, 2003).

Tungkai kaki disebut juga sebagai kerangka anggota gerak bawah (ekstremitas bawah). Anggota gerak bawah terdiri atas tiga puluh satu tulang yaitu sebagai berikut: 1) 1 tulang koxa/tulang pangkal paha, 2) 1 femur/tulang paha, 3) 1 tibia/tulang kering, 4) 1 fibula/tulang betis, 5) 1 patela/tempurung lutut 6) tulang tarsal/tulang pangkal kaki, 7) tulang metatarsal/tulang telapak kaki 8) 14 falanx/ruas jari kaki (Evelin C. Pearce, 2005). Dengan pengukuran panjang tungkai kaki dapat diketahui informasi lengkap mengenai ukuran seluruh panjang tungkai tersebut. Pengkuran anggota tubuh bagian bawah dan bagian khususnya tidak dapat dilakukan setepat ukuran anggota tubuh bagian atas Achmad Sofyan Hanif, 2011).

Di sisi lain, sistem alat gerak manusia terdiri dari otot dan tulang. Otot merupakan alat gerak aktif, gerakan tersebut disebabkan karena kerjasama otot dan tulang yang berkontraksi. Selain itu komponen yang dibutuhkan dalam atletik lompat jangkit untuk mendukung jangkauan langkah dan jauh lompatan adalah komponen kondisi fisik, teknik serta proporsi fisik yang bagus didalamnya. Dapat diartikan, Panjang tungkai seseorang didukung kondisi fisik dan teknik yang baik maka mempengaruhi langkah dan lompatan seseorang. Semakin panjang tungkai atlet maka akan semakin panjang langkah atlet, dan semakin panjang langkah atlet maka diharapkan semakin jauh pula lompatan atlet.

\section{METODOLOGI}

\section{Study participants}

Populasi adalah keseluruhan individu yang akan dijadikan objek penelitian dan keseluruhan dari individu tersebut paling sedikit mempunyai satu sifat yang sama (Homogen). Homogen adalah sumber data yang unsurnya memiliki sifat yang sama sehingga tidak perlu mempersoalkan jumlahnya secara kuantitatif. Metode ini dilakukan pada populasi sasaran (target population) penelitian adalah seluruh atlet Triple Jump yang berjumlah 33 atlet.

\section{Study organization}

Jadi, model path analysis digunakan untuk menganalisis pola hubungan antar variabel dengan tujuan untuk mengetahui pengaruh langsung seperangkat variabel 
bebas (eksogen) terhadap variabel terikat (endogen). Variabel yang dikaji terdiri dari dua variabel yang terdiri dari tiga variabel eksogen (bebas) dan satu variabel endogen (terikat). Variabel eksogen terdiri dari panjang tungkai $\left(\mathrm{X}_{1}\right)$ dan Variabel endogen terdiri dari hasil lompat jangkit $(Y)$. Pola keterkaitan antar variabel penelitian terlihat pada gambar berikut ini:

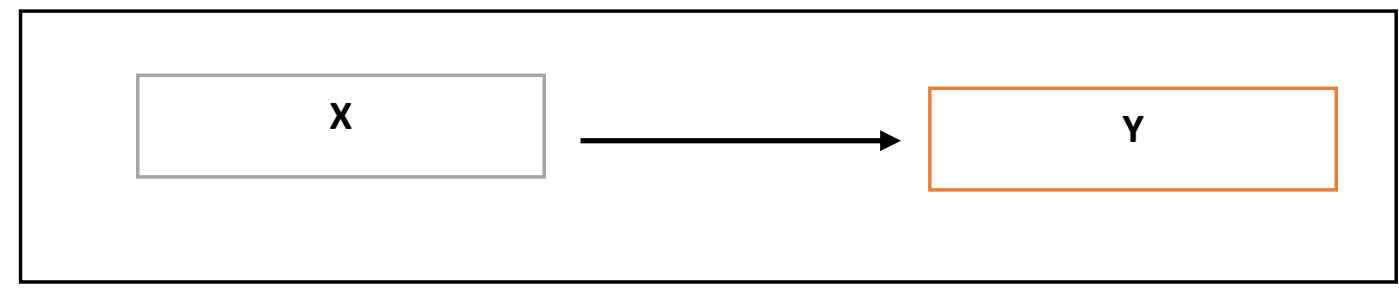

$\begin{array}{ll}\text { Keterangan: } & X=\text { Variabel Panjang Tungkai } \\ & Y=\text { variabel Hasil Atletik Triple Jump }\end{array}$

Bagan 1. Konstelasi Antar Korelasional Variabel

Jadi rancangan penelitian ini yaitu mengukur panjang tungkai yang dihubungkan dengan Hasil Atletik Triple Jump.

Testing procedure.

Untuk mengumpulkan data penelitian digunakan instrumen penelitian. Instrumen penelitian ditempuh melalui beberapa cara, yaitu (a) menyusun indikator variabel penelitian, (b) menyusun kisi-kisi instrumen, (c) melakukan uji coba instrumen, (d) melakukan pengujian validitas dan reliablitas instrumen. Sesuai dengan jenis variabelvariabel yang dilibatkan dalam penelitian maka untuk mendapatkan data yang diolah dalam penelitian ini, maka instrumen yang digunakan adalah (1) Instrumen lompat jangkit $(Y)$ dengan mengukur hasil lompatan, (2) Instrumen panjang tungkai $\left(X_{1}\right)$ dengan menggunakan alat ukur panjang tungkai.

\section{HASIL PENELITIAN}

Berhubung karena pengolahan data dalam penelitian ini menggunakan uji statistik dengan teknik analisis jalur (path analysis), maka perlu dilakukan uji persyaratan analisis, sehingga hasilnya dapat digunakan untuk menarik kesimpulan. Pada penelitian ini uji persyaratan yang dimaksud adalah uji normalitas.

\section{Uji Normalitas}

Berdasarkan hasil perhitungan uji normalitas liliefors diperoleh harga $L_{0}$ sebesar 0,1090. Dimana nilai kritis Lo pada tabel liliefors untuk ukuran sampel $(n)=33$ dengan $a=0,05$ diperoleh nilai sebesar 0.285 . Jika dibandingkan nilai L0 hitung ternyata lebih 
kecil dari L0 tabel, sehingga dapat disimpulkan bahwa uji normalitas $\mathrm{X}_{1}$ berdistribusi normal. Selanjutnya Berdasarkan hasil perhitungan uji normalitas liliefors diperoleh harga $L_{0}$ sebesar 0,1185 . Dimana nilai kritis $L_{0}$ pada tabel liliefors untuk ukuran sampel $(n)=33$ dengan $a=0,05$ diperoleh nilai sebesar 0.285. Jika dibandingkan nilai $L_{0}$ hitung ternyata lebih kecil dari $L_{0}$ tabel, sehingga dapat disimpulkan bahwa uji normalitas $Y$ berdistribusi normal.

\section{Uji linearitas regresi}

Berdasarkan hasil perhitungan uji linieritas regresi diperoleh $F f_{\text {hitung }}$ sebesar 2.007. Dimana nilai kritis $F_{\text {tabel }}$ untuk ukuran sampel $(n)=8$ dengan $F$ tabel diperoleh

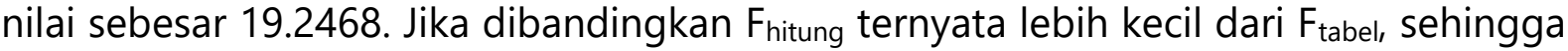
dapat disimpulkan bahwa uji linieritas data ini maka regresi linier. Dan untuk menguji signifikan regresi dengan ketentuan Fhitung > Ftabel maka uji regresi signifikan. Maka dengan uji signifikan regresi $\mathrm{X}_{1}$ terhadap $\mathrm{Y}$ terdapat thitung 24.9764 dan $\mathrm{T}_{\text {tabel }}$ terdapat 5.99 maka dapat disimpulkan regresi signifikan.

Uji Hipotesis

Uji secara individual ditunjukkan oleh tabel Coeficients, bahwa hasil koefisien jalur $p_{y \times 1}=0,002$

Tabel 1. Model Summary

\begin{tabular}{|c|c|c|c|c|c|c|c|c|c|}
\hline \multicolumn{10}{|c|}{ Model Summary ${ }^{b}$} \\
\hline \multirow[b]{2}{*}{ Model } & \multirow[b]{2}{*}{$\mathrm{R}$} & \multirow[b]{2}{*}{ R Square } & \multirow[b]{2}{*}{$\begin{array}{l}\text { Adjusted R } \\
\text { Square }\end{array}$} & \multirow[b]{2}{*}{$\begin{array}{l}\text { Std. Error of } \\
\text { the Estimate }\end{array}$} & \multicolumn{5}{|c|}{ Change Statistics } \\
\hline & & & & & $\begin{array}{l}\text { R Square } \\
\text { Change }\end{array}$ & F Change & $\mathrm{df1}$ & df2 & $\begin{array}{c}\text { Sig. F } \\
\text { Change }\end{array}$ \\
\hline 1 & $.472^{\mathrm{a}}$ & .2228 & .774 & .35922 & .2228 & 29.976 & 1 & 6 & .002 \\
\hline
\end{tabular}

a. Predictors: (Constant), Panjang Tungkai

b. Dependent Variable: Hasil Lompat Jangkit

Hipotesis penelitian yang akan diuji dirumuskan berbentuk hipotesis statistik sebagai berikut:

$$
\begin{aligned}
& \text { Ha: } p_{y x 1}>0 \\
& \text { Ho: } p_{y x 1}=0
\end{aligned}
$$

Hipotesis bentuk kalimat

Ha: Panjang tungkai berkontribusi terhadap hasil lompat jangkit

Ho: Panjang tungkai tidak berkontrbusi terhadap hasil lompat jangkit.

Dari tabel 1. Coefficients, didapat nilai sig. 0.002. Ternyata nilai sig. 0.002 lebih kecil dari nilai probabilitas 0.05 atau nilai $0,05>0.002$, maka $\mathrm{H}_{a}$ diterima dan $\mathrm{H}_{0}$ ditolak artinya koefisien analisis jalur adalah signifikan. Jadi panjang tungkai berkontribusi terhadap 
hasil lompat jangkit. dan signifikan panjang tungkai dengan pukulan smash sebesar $(r=0.472)$ dan $\left(r^{2}=0.472=0.472^{2}=0.2228\right)$ dengan kontribusi panjang tungkai memberikan kontribusi sebesar 22.28\% terhadap hasil Atletik Triple Jump.

\section{PEMBAHASAN}

Berdasarkan hasil pengujian dari penelitian yang telah dilakukan pada bagian pengujian hipotesis, maka dapat dinyatakan bahwa: Pertama, hipotesis terdapat pengaruh signifikan panjang tungkai terhadap hasil lompat jangkit. setelah dilakukan pengujian hipotesis terbukti secara langsung signifikan pengaruhnya terhadap hasil lompat jangkit. Temuan ini menunjukkan, bahwa untuk meningkatkan hasil lompat jangkit atlet harus memiliki panjang tungkai yang baik dimana keduanya memiliki kontribusi yang cukup besar.

\section{KESIMPULAN}

Berdasarkan analisis data dan perhitungan statistik yang diuraikan dari pembahasan hasil penelitian yang dilakukan pada atlet atletik Pelatda Pekanbaru, maka pada bab dikemukakan kesimpulan bahwa terdapat pengaruh positif langsung daya ledak otot tungkai $\left(\mathrm{X}_{1}\right)$ terhada hasil lompat jangkit $(\mathrm{Y})$ pada Unit Kegiatan Mahasiswa (UKM) Penjas Universitas Pahlawan Tuanku Tambusai.

\section{HAMBATAN DAN KENDALA}

Tidak ada kendala dalam penelitian ini.

\section{DAFTAR PUSTAKA}

Ahmad Pratama, S. (2020). Perbandingan Ketepatan Menendang Kearah Gawang: KuraKura (Dalam Vs Luar): Comparison Of Accuracy Shooting: Turtle Technique Analysis (Inside Vs Outside). INSPIREE: Indonesian Sport Innovation Review, 1(1), 36-44. https://doi.org/10.53905/inspiree.v1i1.3

Carr, Gerry A. 2003. Atletik Untuk Sekolah. Jakarta: PT RajaGrafindo Persada.

Djumidar. 2004. Gerak-Gerak Dasar Atletik dalam Bermain. Jakarta:PT RajaGrafindo Persada.

Rizky, E. (2020). Analysis Of Soccer Shooting Skills: Effects Of Power And SelfConfidence Athletes.: Analisis Keterampilan Shooting Sepak Bola: Peran Dari Kekuatan Dan Rasa Percaya Diri Atlet. INSPIREE: Indonesian Sport Innovation Review, 1(1), 16-23. https://doi.org/10.53905/inspiree.v1i1.4 
Hanif, Achmad Sofyan. 2011. Kepelatihan Dasar Sepak Takraw. Jakarta: Bumi Timur Jaya Guthrie, Mark. 2003. Sukses Melatih Atletik. Pustaka Ihsan Madani.

Mane, Fred Mc. 2008. Dasar Dasar Atletik. Bandung: Percetakan Angkasa.

Pearce Evelin C. 2005. Anatomi dan Fisiologi untuk Paramedis. Jakarta: PT Gramedia

Suherman, Adang dkk. 2001. Pembelajaran Atletik, Pendekatan Permainan dan kompetisi Untuk siswa SMU/SMK. Jakarta: Dirjen Olahraga, Depdiknas. 


\section{LAMPIRAN}

\section{Informasi Tentang Penulis:}

Dr. Herli Pardilla, M.Pd:

Email:herlipardilla@gmail.com; https://orcid.org/0000-0001-6777-3479;

https://www.scopus.com/authid/detail.uri?authorId=57214080181; Department of

Physical Education, faculty of Education at Universitas Pahlawan Tuanku Tambusai. Tuanku Tambsuai Street, No. 23, Bangkinang City, 28412, Indonesia.

\section{Iqbal Husnayadi:}

iqbalhusnayadi1999@gmail.com; https://orcid.org/0000-0002-8292-6864; Department of Shariah and Law, faculty of Syariah at International University of Africa, Madani St. Khartoum 12223, Sudan. 